\title{
O wyznaniu kanarka, dzieciach na kolonii i apologii wszy planowanej przez Janusza Korczaka
}

Pamiętnik Janusza Korczaka jest tekstem bardzo mocnym. Niemal cały napisany został w roku 1942, w getcie, w budynku o podwójnym adresie: Sienna 16 / Śliska 9, w ostatnim miejscu, dokąd przeniesiono Dom Sierot. Przetrwał ukryty po aryjskiej stronie w Naszym Domu dla dzieci polskich. Korczak pisał wytrwale. Napisawszy fragment, nie wracał do niego. Używał pióra lub ołówka, który „poczciwy Felek naostrzył”. Zdarzyło się, że przy pisaniu popijał spirytus pół na pół z gorącą wodą, że pisał, czując zapach amoniaku, bo „mocz teraz szybko rozkłada się, a nie co dzień płuczę kubeł” '. Szczery całkowicie, niebojący się żadnych słów. Pisał w izolatce, gdzie leżeli chorzy ${ }^{2}$, tam miał swoje łóżko i stół. Pisał nocą. Także o tym, kiedy i jak pisze. Zdawał sobie z pewnością sprawę, że każdy z tych zapisków, nieobmyślanych jakoś szczególnie, nieupozowanych autorsko, może mieć wagę życiowego testamentu. Wiele $\mathrm{z}$ nich to jakby opracowane raz jeszcze "prawidła życia” " Inne stają się pobieżnym rejestrem zmagań i upokorzeń. Są i notki azyle. Na jednej z pierwszych stron, dopiero po wyliczeniu przyszłych autorskich zamierzeń i utrwaleniu marzenia o „wojnie” - czyli rywalizacji poetów i muzyków, zamieścił rozbrajającą konstatację, wtrąconą

I J. Korczak, Pamiętnik, w: idem, Wybór pism, t. 4, Warszawa 1958, s. 538-539. Dalej cytaty z tego wydania oznaczam numerem strony podanym w nawiasie.

${ }^{2}$ Chorych było kilkoro, właściwie niewielu, bo wciąż udawało mu się zapewnić jako taki byt swoim przeszło dwustu podopiecznym. Podobno utrzymywał dzieci w dobrej formie dzięki wpływaniu na ich ducha - odrywał je od rzeczywistości baśniami i opowieściami - zob. J. Olczak-Ronikier, Korczak. Próba biografii, Warszawa 2011.

3 Korczak wydał w roku 1930 w wydawnictwie Jakuba Mortkowicza książkę pod tytułem Prawidła życia. Pedagogika dla młodzieży $i$ dorostych. 
jakby przy okazji: „Zapomniałem nadmienić, że i teraz jest wojna" ${ }^{4}$ (s. 514).

Warte odnotowania były nawet drobiazgi, jak te ołówki Felka, albo że „Albert odciemnił pokój” (s. 552) - ulga, którą przynosi człowiekowi działanie drugiego. Dalej - obserwacje dzieci, zalecenia pedagogiczne. Rozmyślania, na przykład o eutanazji. Szkice stosunków panujących w getcie. I wreszcie obrazki oparte na zestawieniu Polak - Żyd, polskość - żydowskość, chrześcijaństwo - judaizm. Korczak wspomina swe przedwojenne wizyty lekarskie, również u bogatych Polaków, choć „lekarze, Żydzi, nie mieli chrześcijańskiej praktyki” (s. 557). Opowiada o spotkaniu w getcie dawnego wychowanka, teraz - przemytnika, i o obserwujących ich rozmowę ,zgorszonych katolikach w opaskach”. Przytacza poruszający list dzieci, który „w tej chwili przyniósł mu Semi” do korekty - w liście prośba do „Sz. Ks. Plebana o łaskawe udzielenie nam pozwolenia na kilkakrotne odwiedzenie ogrodu przy kościele w soboty, w godzinach rannych, możliwie wczesnych (6:30-10). Tęsknimy za trochę powietrza i zieleni” (s. 548). Nie ukrywa swojego przekonania o konieczności zakazu kontaktów „między kanalią żydowską i elitą duchową, moralną Polaków” (s. 516). Szkicuje zapamiętany obraz „rozwalonej na krześle, obrosłej sadłem Żydówy” (s. 517), która pogardliwie traktuje mądrego i dobrego polskiego szewca o „przeduchowionej” twarzy. I jeszcze dokumentuje wrażenia z lektury, konfrontując kulturę łacińską ze starotestamentową: „Czy Marek Aureliusz czytał przypowieści Salomona? Jakże kojąco działa jego pamiętnik” (s. 594). A na przedostatniej stronie zapisuje: „Ojcze nasz, który jesteś na niebiesiech...” (s. 598).

Wśród tych uwag napotykamy również prawdziwie pamiętnikowe powroty do dzieciństwa, do którego w końcu zawsze się myślami wraca, czasu najważniejszego dla dalszych wyborów: „Ojciec miał prawo nazwać mnie Henrykiem, bo sam otrzymał imię Józef. I inne dzieci nazwał dziadek chrześcijańskimi imionami..." (s. 586). Autor wspomina mamę, ojca, babcię... Najważniejsze osoby. A jednak nie one stały się bohaterami sceny opisującej dotkliwą inicjację dziecka w tożsamość i w „zagadnienie wyznania”. Odbyła się ona przypadkiem za sprawą małego, niewinnego stworzenia, które samo w sobie jest pozbawione mitycznej, legendarnej czy historycznej symboliki.

4 W dalszej części pamiętnika Korczak opowiada o wojnie w sposób sobie właściwy: reportażowo, obrazkami, dialogami, krótkim komentarzem, pytaniem retorycznym, elipsą. Czasem nawet $\mathrm{z}$ humorem, autoironią, choć nie był już wtedy wcale pełnym humoru dawnym Korczakiem; na rzeczywistość reagował ostro, emocjonalnie. 
[...] pod kasztanami pochowany był w wacie w blaszanym pudełku od landrynek mój zmarly bliski i kochany, na razie tylko kanarek. [...] Chciałem na jego grobie postawić krzyż. Służąca powiedziała, że nie, bo on ptak, coś bardzo niższego niż człowiek. Płakać nawet grzech. Tyle służąca. Ale gorsze to, że syn dozorcy domu orzekł, że kanarek był Żydem.

I ja.

Ja też Żyd, on - Polak, katolik. On w raju, ja natomiast, jeśli nie będę mówił brzydkich wyrazów i będę mu posłusznie przynosił kradziony w domu cukier - dostanę się po śmierci do czegoś, co wprawdzie piekłem nie jest, ale tam jest ciemno. A ja bałem się ciemnego pokoju. (s. 513)

Biedny kanarek został po śmierci zdegradowany w oczach chłopca zarówno pod wpływem opinii reprezentatywnej dla katolicyzmu (stworzenie niższe, brak duszy) 5 , jak i w wyniku uświadomienia dziecku innej, wyznaczonej pochodzeniem, drogi, z wysoce nieprzyjemną, odstraszającą wizją szeolu u kresu. Lapidarnie i po mistrzowsku nakreślona przez Korczaka scena.

Dzieje kanarka, który pod koniec XV stulecia przybył do Europy, są chyba za krótkie, by uwzględnić go w słownikach symboli (a znajdują się w nich przecież inne gatunki ptaków), jednak jego postać nie jest wolna od pozytywnych asocjacji. Obecnie kanarki niemal znikły $\mathrm{z}$ naszych mieszkań, ale przed wojną uchodziły za nieodłącznych towarzyszy rodziny. Wymienić można by zatem pod hasłem „kanarek” nie tylko cechy gatunkowe, ale i dobro, i piękno, delikatność, radość, miłość, rodzinę... A myśląc o wzajemnej relacji kanarka i osamotnionego dziecka, dziecka indywidualisty, nie każdego dziecka, należałoby jeszcze dodać więź, poczucie wyjątkowości, słodycz opieki, działania dla czyjegoś dobra. Nie mniej istotne byłyby w tym opisie powierzane przyjacielowi tajemnice i pewna wspólnota losu (ograniczenia, wstydliwa niedogodność braku wiedzy), a także wzajemne pocieszanie w niedoli.

Służąca i syn dozorcy przez swoje niebaczne słowa to wszystko zniszczyli. Mały Henryk Goldszmit zrozumiał, że w przekonaniu służącej, którą trzeba szanować, oraz w twardym światopoglądzie jego cenionego bardzo, aczkolwiek nieakceptowanego przez rodziców kolegi, bycie ptakiem i bycie Żydem sygnuje nieodwołalnie i bez żadnych wątpliwości gorszą jakość. Nie tylko tego, co czeka kanarka $\mathrm{i}$ jego właściciela w pośmiertnej przyszłości, ale

5 O przekonaniach dotyczących zwierząt w kontekście religii - zob. J. Abramowska, Pokrewieństwo i różnica, w: eadem, Pisarze wzwierzyńcu, Poznań 2010, s. $9-46$. 
i tego, co wiąże się z egzystencją doczesną ich obu. W dodatku owo rozpoznanie nastąpiło po tym, jak dziecko zaczęło wieść egzystencję samotną, bez towarzysza. Osierocony człowiek, pierwszy raz obrzucony nazwą swojego narodu jak obelgą.

Akurat w tej sytuacji niepomyślne okazuje się pozostawanie chłopca między dwoma światami, których istnienia do tego momentu nie przeczuwał, wychowując się w spolonizowanej rodzinie. Gdyby jego rodzice byli religijni, rzecz mogłaby się zakończyć inaczej. Chłopcu nie przyszłoby do głowy ustawianie krzyża na grobie, a najwyżej taka prośba, której spełnienie ugruntowuje wspólnotę i aprobuje za jej sprawą tożsamość kanarka - jak w scenie z getta, której bohaterem jest także kanarek Żyd:

Mieszkał w klatce, żółty jak cytryna. Jadał specjalny pokarm dla ptaków, takie drobne, brązowe ziarenka. Był do nich przyzwyczajony, potem nie chciał niczego innego, a ziarenek już nie było. Wreszcie Fenka, moja mama, powiedziała, że trzeba go wypuścić. „Może uda mu się przelecieć przez mur? Przecież nie ma na czole napisane, że jest żydowskim kanarkiem?”, mówiła. Chana płakała, była taka malutka, niczego nie rozumiała, ale kiedy mama otworzyła klatkę, Chana krzyknęła: „On zginie! Zabiją go inne ptaki!” I mama zawahała się, a następnego dnia było już za późno. Wieczorem Chana poprosiła ojca: „Tatusiu, odmów kadisz, nasz kanarek umarł”. Moja ciotka oburzyła się: „Coś ty, Chana, kadisz za kanarka?” A moja mama powiedziała: „Dlaczego nie?” Ojciec pogłaskał Chanę po głowie: „Dobrze, córeczko, odmówię kadisz za niego"6.

Fragment ten wskazuje bolesną paralelę losu: należącemu do wspólnoty kanarkowi, mimo że „nie ma na czole napisane, że jest żydowskim kanarkiem”, dane są takie same szanse przeżycia jak dziecku, które jest niepodobne do żydowskiego dziecka. Jeśli wydostanie się za mur, mogą go jednak zadziobać inne ptaki jak dziecko mogą wydać ludzie. Podobną paralelę losu kanarka i człowieka znajdujemy u Korczaka.

Wspominając bolesny epizod związany z pogrzebem ptaszka, Korczak odsłania czytelnikowi pierwowzór sceny zamieszczonej w powieści Król Maciuś na bezludnej wyspie. Epizod ten nakreślony został z godną podziwu znajomością odczuć i zachowań dziecka w sytuacji, gdy zauważa ono śmierć zwierzątka. Fragment - sformułowany w mowie pozornie zależnej - ukazuje małego bohatera, który zbyt późno kojarzy fakt choroby, próbuje podjąć reanimację, okleiwszy zaś później zielonym papierem tru-

\footnotetext{
${ }^{6}$ K. Siesicka, Cbwileczkę, Walerio, Wrocław 1997, s. 41.
} 
mienkę z pudełka, kryje się z tym przed dorosłymi, żeby go nie wyśmiali. Wreszcie pogrzeb i po nim dylemat: „Zakopał Maciuś pudełko, z kamyków zrobił wzniesienie i nie wie, czy można postawić krzyżyk, czy nie wolno" 7 . W przypadku Maciusia problem nie dotyczy oczywiście kwestii wyboru tradycji ${ }^{8}$, dotyczy jedynie przekonania o niższości pozbawionych duszy zwierząt w hierarchii świata. Jest smutnym rozstrzyganiem kwestii szacunku dla przekonań religijnych, w tej sytuacji sprzecznych z miłością i przywiązaniem do zmarłej istoty.

Dla Maciusia śmierć kanarka była znakiem zmiany losu na gorsze. Śmierć kanarka była znakiem z innego wymiaru, spoza łatwych uzasadnień, świadczyła o tym, że jednak stało się coś niezwykłego i ważnego. Ten sam znak - tylko jeszcze spotęgowany - projektował dla siebie „jaśnie pan” z Pałacu Wiesława Myśliwskiego: „[...] moja śmierć wystawna będzie jak wesele. [...] Niech popamiętają, że jak jaśnie pan umierał, to umierał ze wszystkim. Z serca, z duszy, z pragnienia, bólu, cały świat z nim umierał. Nawet kanarki w dzień po nim umarły" ${ }^{9}$. Kanarki oraz inne istoty i przedmioty wymienione dalej w opisie tej królewskiej śmierci służą jaśnie panu do podkreślenia pozycji. Są wykorzystane do radującej serce pracy wyobraźni, bo przecież bohater Pałacu nie jest wcale panem, tylko przypadkowym uzurpatorem, który wszedł do pałacu opuszczonego przez właściciela na wieść o zbliżającej się wojnie. W rzeczywistości to wieśniak, pasterz owiec. Kanarek jest dla niego symbolem pańskości, luksusu, gdy do wszystkich wygód dodane zostały jeszcze te kolejne - zawsze dostępna pociecha, dogodność wzruszeń przy prywatnym, drogo kupionym śpiewaku, radowanie się melancholią bez treści, u szczytu samolubstwa, gdzie nie widać nędzy świata.

Każdy kanarek pałacowy pełni taką samą funkcję - ugruntowuje poczucie wartości właściciela. Monolog bohatera ma też charakter swoiście satyryczny, ale każda satyra musi mieć swe uzasadnienie w powadze rzeczywistości, dlatego i śmieszne, i straszne jest zapewnienie:

To z dziada pradziada kanarek. Z krwi. Nic w nim, już nie mówię, $\mathrm{z}$ wróbla, ale nawet ze słowika nic. To nie kanarek, to już sam śpiew.

7 J. Korczak, Król Maciuśna bezludnej wyspie, w: idem, Dzieła, t. 8, Warszawa 1992, s. 347.

${ }^{8}$ Co ciekawe, Żydzi pojawiają się w tej książce - raz wymienieni wśród grup, których emancypację się omawia, innym razem reprezentowani przez króla Borucha, który oznajmia, że „czekał na królestwo dwa tysiące lat”, co zresztą powoduje niechęć Maciusia do niego. Maciuś uważa go za kłamczucha, bo „najwyżej człowiek żyje sto lat przecież" - zob. ibidem, s. 229-230, 305.

9 W. Myśliwski, Pałac, Warszawa 1998, s. 81. 
Można by powiedzieć wielki, możny kanarek. Jaśnie pan kanarek. On by, nieboraczek, nie potrafił już w powietrzu się utrzymać. Skrzydła ma tylko ku ozdobie. Liście na drzewach byłyby za ostre dla niego. Ziemia za szczerbata ${ }^{\text {Io }}$.

Gdy nakłada się na ten obraz kontekst całego utworu, czytelnik mimowolnie skłonny jest przydać możnemu ptakowi cech możnego pana, samolubnego, apodyktycznego, dumnego - bo takie jest wyobrażenie tej postaci w monologu Jakuba, który swoje prawdziwe pochodzenie zresztą raz po raz demaskuje. Dzieje się tak, kiedy bohater niechcący odkrywa swoje gminne doświadczenie i ujawnia żywiącą się tym doświadczeniem chłopską wyobraźnię, przaśną, wiejską, rodzimą. Z lubością fantazjuje na temat rozkapryszonego, grubego, wyuzdanego z-chłopa-króla, który gotów jest oddać wszystkie ukochane kanarki i konia, i dwórkę temu, kto pokaże, jak się kwartę duszkiem pije, a innym razem - dla zdobycia kanarka! - pozwala na zdradę i aranżuje fałszywą scenę małżeńskiej zazdrości.

Celebrowanie uroczystości pożegnania ulubieńca w Pałacujest jednak nieco podobne do tego, które zaaranżował dla swojego przyjaciela osamotniony król Maciuś na bezludnej wyspie. Wiózł kanarka karawanem - z pudełek - na górę, wśród przyrody. Gdy go pogrzebał, także rozległ się śpiew; to jakiś inny kanarek spośród mieszkających tam zadbał o uroczystą oprawę chwili. Co ciekawe, śpiewak jaśnie pana i Maciusiowy kanarek, który zresztą również nie potrafił już fruwać, choć przedstawione zostały w tak różnym świetle, służą bohaterom podobnie: jako ich ptasie alter ego. Król Maciuś prosi o przysłanie swojego pupila w czasie, gdy uwięziony ma zakaz widywania ludzi dłużej niż czternaście minut. Kanarek od tego momentu jest jedynym jego bliskim, również więźniem (zamkniętym w klatce). W pewnym momencie, po ucieczce Maciusia, strażnicy, widząc kanarka, przypuszczają, że to jest zamieniony czarodziejsko chłopiec, a opis zachowania zwierzątka po dobrowolnym zesłaniu Maciusia na wyspę stanowi prostą alegorię inności pośród istot na pozór tego samego gatunku. Zapewne można by do niej dopasować przeróżne perypetie z odmiennością. Przedstawienie to staje się niezwykle sugestywne, gdy sobie wyobrazimy, że - zgodnie z fabułą powieści - kanarek Maciusia to ktoś zmuszony do życia w cudzym kraju. Spróbujmy czytać alegorycznie:

[...] kanarki bezludnej wyspy - wolne ptaki lasu, nie rozumieją kanarka klatki. I nie lubią się. Kiedy Maciuś wypuścił kanarka z nie-

то Ibidem, s. 150 . 
woli, tamte zaczęły się kłócić, a potem zaczęły dziobać. I kto wie, może by zadziobały kanarka klatki, gdyby Maciuś go nie obronił. Maciuś nie widzi między nimi różnicy. I to ptak, i to ptaki. Kanarek klatki żółty i tamte żółte. I jednakowo ćwierkają. A musi przecież być różnica, kiedy wiedzą. I nie lubią się. Kanarek Maciusia boi się wolnych ptaków. Poskacze z grządki na grządkę - zaćwierka. Tamte posłuchają i coś odpowiedzą. Kanarek klatki stanie w otwartych drzwiczkach, pokręci łebkiem, tak ćwierka, jakby się radził, co robić. Już się przechyla naprzód, żeby wyfrunać. Ale nie: wraca. Albo wyfrunie za klatkę, posiedzi trochę - ale widać, że mu jakoś dziwnie, nieswojo. Taki zdenerwowany, że nie wiem. Poprawia skrzydełka, łebkiem śmiesznie kręci. A tamte coś z nim mówią. Nie wie Maciuś, czy się kłócą, czy się pytają tylko, co on za jeden. Ale zaczyna Maciuś trochę się domyślać. Wychodzi, że mu zazdroszczą złotej klatki, ale się wyśmiewają, że fruwać zapomniał.

„Przyzwyczai się - myśli Maciuś. - Z pewnością mój kanarek może je wiele nowego nauczyć”. A tamte wiedzą wiele, czego nie wie kanarek Maciusia ${ }^{\text {II }}$.

Dwa ostatnie zdania to już zaszyfrowany program, wielkie marzenie Korczaka - współistnienie bez wzajemnego niszczenia się, wzajemna pomoc. Jako pedagog, psycholog dziecięcy, działacz socjalny chciał przede wszystkim, by ludzie zrozumieli, że dziecko jest dzieckiem (czyli człowiekiem). Że przede wszystkim jest dzieckiem, a dopiero później Żydem czy Polakiem. Nie można było chyba sprytniej i mądrzej oddać tego przesłania niż przez publikację dwóch książek, jednej po drugiej (w odcinkach w „Promyku” 1909-1910, jako wydawnictwo zwarte - w latach 1910-1911). Pierwsza nosi tytuł: Mośki, Joski i Srule, druga Józki, Jaśki i Franki. Stanowią one zapis doświadczeń autora zebranych na koloniach letnich, zorganizowanych przez Warszawskie Towarzystwo Kolonii Letnich dla dzieci biednych i w złym stanie zdrowia.

Niejeden raz „dozorca”, czyli narrator, porównuje polskich i żydowskich podopiecznych: chłopcy tak samo są spokojni i niespokojni, naiwni i sprytni, samolubni i uczynni, chętni do zabaw i nieumiejący się bawić, mają zmartwienia związane z rodziną, płaczą, tak samo cieszą się na zorganizowany koncert, modlą się podobnie, choć z innych modlitewników. Korczak marginalizuje wszelkie różnice kultur czy stopnie asymilacji, wysuwając na pierwszy plan podobieństwo przeżyć i uczuć. Korczak zdaje się wcale nie zakładać takiego zrównania charakterów polskich i żydowskich dzieci, obserwuje dokładnie, czy nie uwidocznią

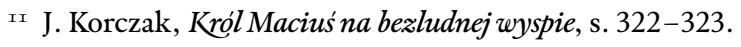


się jednak przypisywane tym drugim naganne cechy, co opisuje $\mathrm{z}$ ironią $\mathrm{w}$ następnych wspomnieniach kolonijnych:

Dziw: biegną na wyścigi do rzeki, choć chłodny wiatr przewiewa, a woda zimna.

Dziw: z kwiatów polnych układają wiązanki, a każda wiązanka ma swój własny wdzięk. [...]

Dziw: pozrzucali bluzy, chwycili za łopaty i kopią fortecę dla przyszłej wojny. Policzki się rumienią, pot spływa z czoła. [...]

Więc nie boją się wody, więc jest w nich poczucie piękna, więc znajdują rozrywkę w pracy fizycznej? ${ }^{\text {I2 }}$.

W innym miejscu wyjaśnia rozgoryczony:

Spotkał mnie zarzut (prywatny), że chłopcy na moich kolonijnych obrazkach za mało są Żydami, że są to sobie dzieci na wsi, a nie żydowskie dzieci.

Uwaga pozornie słuszna: i ja początkowo szukałem w nich cech specyficznie żydowskich; cóż robić jednak: nie znalazłem. Szukałem i nie znalazłem ${ }^{\mathrm{I}}$.

Wymienia wady, czerpiąc obficie z panującego wówczas stereotypu Żyda: tchórzliwość, brud, spryt, lenistwo, kłamstwo, krętactwo... Każdą z nich potwierdza: „byli i tacy” i zaraz mocniej zaprzecza: ,ale większość...”. Każdą skazę w zachowaniu czy osobowości dziecka można tłumaczyć nieprawidłowym wychowaniem. I autor ucina: „A gdyby im pozwolić bić się na serio, powybijaliby sobie zęby nie gorzej niż chrześcijańscy chłopcy”. To samo dotyczy zalet: „Tego wszystkiego można nie zauważyć ani tu, ani tam - jeśli się szukać nie umie czy nie chce..." I4.

A jednak między polskimi i żydowskimi dziećmi jest istotna różnica. Dotyczy ich postrzegania przez polskich sąsiadów. Kiedy Korczak opisuje w Michatówee przygotowanie do pieszych wycieczek, które mogą być zorganizowane dopiero wtedy, „gdy ma się pewność, że dzieci szkody w drodze nie będą robiły", dodaje zaraz twardo: „[...] dotyczy to przede wszystkim, rzecz jasna, kolonii żydowskich" ${ }^{5}$. Smutek z tym związany pojawia się w Mośkach, Joskach i Srulach raz po raz, zakłócając radość opisu

${ }^{12}$ J. Korczak, Mośki, Joski i Srule. Wrażenia z kolonii letniej w Daniłowie, w: idem, Dzieta, t. 5, Warszawa 1997, s. 288-289.

${ }^{\prime} 3$ J. Korczak, Michałówka. Kolonia dla dzieci żydowskich (z notatek dozorcy), w: idem, Dzieła, t. 5, s. 270.

${ } 4$ Ibidem.

I5 Ibidem, s. 284. 
przyjaznej dzieciom przyrody, niestęchłego powietrza, niewilgotnych ścian, zabaw, samego zdrowia. Nadziwić się nie może Korczak dobroci jednego z chłopów, który pozwolił dzieciom chodzić (boso) po koniczynowym polu, żeby nie musiały jeść podwieczorku na zapylonej drodze. Z goryczą przypomina, że są to dzieci, „których w mieście nie wpuszczą do żadnego ogrodu, woźnica biczem spędzi z ulicy, przechodzień zepchnie z trotuaru, a stróż miotłą zgoni z podwórza. To nie dzieci, to Mośki" ${ }^{{ }^{6} 6}$. $\mathrm{Z}$ bólem odnotowuje dziecięcą „niewiarę w możliwość sympatii, współczucia ze strony tych, którzy mówią po polsku, jadają bez czapki i piszą w sobotę" ${ }^{17}$. Z humorem, aluzyjnie włącza w tę grupę samego siebie, pamiętając o swej, przytoczonej w innym miejscu, poważnej rozmowie z dziećmi żydowskimi. Upomniały go one, że pewne rzeczy są „u nich” niedozwolone - na przykład pisanie i palenie papierosów w sobotę. „U nich”, to jest u Żydów, nie u ludzi, do których zaliczały wychowawcę. Przytaczając epizod o przełamaniu oporu dzieci w sprawie liczenia par, Korczak wybucha nagle:

Toć to lud, gdzie nie ma analfabetów - z prastarą kulturą - inteligencją żywą, silną. - Toć my chyba wiemy, żeśmy nie gorsi, ani głupsi, ani bardziej leniwi? - Ile wieków przejść ma jeszcze - na co czekamy? - Jak długo jeszcze frymarczyć będziemy już nie wiarą, ale naszym przodownictwem duchowym - my, legion, którzy nie więcej wiemy o Żydach, tylko że są brudni i zacofani i mówią nieestetycznym językiem. [...] Nieco samoanalizy, krytycyzmu, godności czy uczciwości nie narodowej, ale ludzkiej! $!^{18}$.

Jedną z zasad kolonii letnich był zakaz męczenia zwierząt. Kto go nie przestrzegał, oddawany był pod słynny dziecięcy sąd. Motyw złego traktowania zwierząt raz po raz objawia się w utworach literackich i pismach Korczaka. Przeplata się jednak z innymi fragmentami, które ukazują - by tak rzec - użytkowy do nich stosunek. Gdyby Korczak pisał powieści o królu Maciusiu dzisiaj, nie mógłby już z taką radością budować w stolicy Maciusia zoo ani bezrefleksyjnie wypuścić z niego w czasie wojny dzikich zwierząt na postrach wroga ${ }^{\text {I9 }}$. Wydawca zaprotestowałby też przeciw takiej suchej minirelacji o postępowaniu sprytnej czarnoskórej królew-

${ }^{16}$ J. Korczak, Józki, Jaśki i Franki, w: idem, Dzieła, t. 5, s. 71.

${ }^{17}$ J. Korczak, Mośki, Joski i Srule..., s. 288.

${ }^{18}$ J. Korczak, Michałówka..., s. 258.

I9 Ale to nic w porównaniu z problemem Murzynów-ludożerców w tej powieści, z oceną „czarnych dzieci”, które są uznane za gorsze, w jednym z epizodów nawet myją się w nadziei, że się wybielą. 
ny: „Klu-Klu miała psa. Klu-Klu otruła psa i zakopała w nocy” ${ }_{20}$ (by pomóc przyjacielowi). Niekiedy i w tej książce bohaterowie litują się nad zwierzętami, ale wspomaga tę postawę antropomorfizacja, charakterystyczna dla baśni i dziecięcego myślenia jak w epizodzie ze szczurkiem pocztowym albo gdy Maciuś łowi ryby, wypuszcza je, a one się cieszą, bo „myślały, że już nie ma ratunku” ${ }^{2 I}$. Podobnie można litować się nad żabami, jeśli szacuje się ich postać $\mathrm{i}$ egzystencję z ludzkiego punktu widzenia, który Korczak nazywa filozoficznym: „Dlaczego Bóg stworzył żaby? Przecież im jest nieprzyjemnie” ${ }^{22}$. W Pedagogice żartobliwej Korczak relacjonuje takie wnioski chłopca: „I lepiej (chociaż różne troski), lepiej urodzić się człowiekiem; bo źrebak ma ciężkie życie. I motyl też. I rybka. A człowiek król!”. W innym miejscu tej książki wspomnienie spontanicznej obrony konia smaganego batem przez woźnicę tramwaju jest pretekstem do udzielenia małym słuchaczom rady, by nie wtrącać się do pracy innych, jeśli nie można im pomóc, i aby samemu pracować najciężej, zdobyć się na jak największy wysiłek ${ }^{23}$. Z kolei w Prawidłach życia opowieści o zabiciu psa i ptaszka służą za przykład dziecięcej wrażliwości, „poezji młodych” ${ }^{24}$. A zwierzęta niepozostające w służbie literatury czy pedagogiki? Gdzie opinia samego Korczaka?

Tak dalece przyzwyczailiśmy się do Korczakowego mówienia głosem dziecka, że zaskakujący wydaje się w Pamiętniku głos jego, własny. Stary Doktor zaczyna swe zapiski od rozważań na temat starości i chociażby mówił za pośrednictwem „ty” lub „on”, wyczuwamy, że te zaimki pseudonimują „ja”. Bezpośredniość diagnoz porusza. Zgromadzone doświadczenie życiowe autora, coraz gorsze warunki życia i bliskość śmierci - to wszystko wpływa zapewne na szokujące oceny, takie jak ta:

Ze zdumieniem dowie się człowiek przyszłości, że jako ozdobę mieszkań używaliśmy cięte kwiaty. I obrazów na ścianach. I jako dywany skórę zwierząt.

Skalpy, skalpy kwiatów i szlachetnych młodszych naszych braci w życiu.

I płótno wypacykowane, na które po pewnym czasie przestaje się patrzeć, a na którym osiada kurz, a pod nim gnieździ się robactwo. (s. 523)

${ }^{20}$ J. Korczak, Król Maciuśna bezludnej wyspie, s. 302.

${ }^{21}$ Ibidem, s. 329.

22 Ibidem, s. 320.

23 J. Korczak, Pedagogika żartobliwa. Moje wakacje. Gadaninki radiowe Starego Doktora, w: idem, Wybór pism, t. 4, s. 156, 190.

${ }_{24}$ Zob. J. Korczak, Prawidta życia, w: idem, Wybór pism, t. 4, s. 100-101. 
Korczak potępia pychę człowieka przejawiającą się w dążeniu do posiadania umownie pięknych i umownie wartościowych rzeczy. Piętnuje ludzkie poczucie wyższości wobec roślin i zwierząt, pozwalające na zabijanie ich w imię estetyki. Ten głos pasowałby do naszych czasów, mógłby przydać się we wstępie do pracy o prawach i godności osobistej zwierząt, jednej z tych pozycji, które pojawiły się $\mathrm{w}$ katalogach bibliotek w większości dopiero po roku 2000. Co sprawiło, że Korczak, tracący wiarę w przetrwanie Domu Sierot, widzacy trupy na ulicach, nędzę i podłość w przytułku na ulicy Dzielnej, gdzie umierało dziennie od dziesięciorga do piętnaściorga pozbieranych z miasta dzieci, pisze o skalpach kwiatów i zwierząt, uznanych za niższe i służebne, i potępia to jako bezsens służący próżności ludzkiej? A może te straszne doświadczenia wyczuliły go bardziej, zobaczył wyraźniej mechanizm: ofiara i - kierujący się wyłącznie pychą - zabójca? Estetyka, projektowany ład świata, wyrastający na śmierci!

Można jeszcze dalej, również szokująco:

Odkładam pióro. Wstać czy nie? Dawno nie kąpałem się. Wczoraj złapałem na sobie i zamordowałem jednym zręcznym uściskiem paznokcia - wesz.

Jeśli zdążę, to napiszę apologię wszy. Bo niesprawiedliwy i niegodny jest nasz stosunek do tego pięknego owada. [...]

Ułożyłem krótką powiastkę o wróblach, które lat dwadzieścia karmiłem. Postawiłem sobie za zadanie zrehabilitować małych złodziejaszków. Ale kto wejrzy w upodlenie wszy?

Kto, jeśli nie ja?

Kto wystąpi, kto będzie miał odwagę wystąpić w jej obronie? (s. 515)

Jak ten fragment tłumaczyć? Jego autor widział rozwieszane w getcie plakaty: „Żydzi - wszy - tyfus plamisty” i z pewnością cień jakiegoś złośliwie gorzkiego uśmiechu przenika jego słowa. Będę bronił wszy, bo jestem Żydem, jestem Żydem i dla kogoś jestem jak wesz, i nikt mnie nie broni. „Upodlenie wszy” - bo są bezwzględnie tępione. Za to tylko, że żyją zgodnie ze swoją naturą. Rehabilitacja wszy? Bo towarzyszą człowiekowi w nędzy? Nie opuszczają go w biedzie? Apologia wszy? Bo dzielnie starają się przetrwać?...

Janusz Korczak pisał Pamiętnik wytrwale, ale bez planu. Nie mógł wiedzieć, który zapis będzie ostatni. Jedno z końcowych zdań brzmi: „Nikomu nie życzę źle. Nie umiem. Nie wiem, jak to się robi”. Pamiętnik zamyka notatką z obserwacji niemieckiego żołnierza. Korczak dziwi się, że żołnierz nie strzela, mimo że, 
jak dodaje ironicznie, „Moja łysina w oknie - taki dobry cel”. Próbuje znaleźć wyjaśnienie, usprawiedliwienie: „Nie ma rozkazu”. Albo: „A może był za cywila nauczycielem na wsi??”; „Może on nie wie nawet, że jest, tak, jak jest? Mógł przyjechać wczoraj dopiero z daleka..." (s. 599).

Żołnierz obserwował Korczaka, gdy ten podlewał w oknie kwiaty.

\section{AGNIESZKA ZGRZYWA}

\section{On the Confession of a Canary Bird, Children on a Holiday Camp, and the Apology for Fleas Planned by Janusz Korczak}

The point of departure for this article is the memory of moving fragments of Janusz Korczak's journal from Warsaw ghetto. The author confronts the fragments with Korczak's earlier texts, such as the short storied about holiday camps for Polish and Jewish children, and the novel Król Maciuś na bezludnej wyspie [King Maciuś on a Desert Island]. The image of a canary bird, used in the novel, is confronted with other symbolic stories about this bird, such as the story in Wiesław Myśliwski's Patac [Palace]. With reference to the image, the article invokes Korczak's meditations on identity and tolerance, and human ethical and aesthetic choices. The audacity of Korczak's thoughts and conclusions goes far beyond his time, and seems perfectly fit for ours.

Keywords: Janusz Korczak, problem of identity, Jews in Poland, rights of children, image of canary bird, memoirs from the ghetto, treatment of animals, Król Maciuś Pierwszy.

Agnieszka Zgrzywa - doktor, wykładowca na kierunku filologia polska jako obca w Collegium Polonicum UAM, inicjatorka działań artystycznych i dydaktycznych tamże. Autorka książek: Stanistaw Grochowiak oraz Poeta i baśń. O Krzysztofie Kamilu Baczyńskim; prowadzi stronę internetową www.poetaibasn.pl. Wśród pasji: recepty Starego Doktora - uwagi i zalecenia Janusza Korczaka oraz thumaczenia tandemowe wierszy srebrnego wieku poezji rosyjskiej. 